\title{
Preferential Ranking of Farmers' Attributes Associated with Welfare of Cross Bred Dairy Cattle in Small Holders' Production System in Assam
}

\author{
Chinmoy Dutta $^{1 *}$, Raj Jyoti Deka ${ }^{1}$, Jyoti Pawan Chutia ${ }^{2}$ and Aditya Boruah ${ }^{3}$ \\ ${ }^{1}$ College of Veterinary Science, Assam Agricultural University, Khanapara, \\ Guwahati, Assam-781022, India \\ ${ }^{2}$ Animal Husbandry and Veterinary Department, Govt. of Assam, India \\ ${ }^{3}$ Lakhimpur College of Veterinary Science, Assam Agricultural University, Joyhing, \\ North Lakhimpur-787051, India \\ *Corresponding author
}

\begin{abstract}
A B S T R A C T
Human- animal relationships are subjected to two primary dimensions: those of affection and utility, which combine together to give a proper shape in animal welfare often expressed in commercial terms when farmers are involved in running a business on livestock. The present study was carried out in purposively selected commercial small holders' dairy farms in and around Guwahati under Kamrup (Metro) District of Assam. A total of 60 dairy farmers were selected based on apparently similar shed and animals following minimum scientific management. A pre tested questionnaire was used for the purpose for preferential ranking of some of the related attributes. During the experiment 24 different attributes were identified for determining the farmers use and non-use value in regards to dairy cow welfare. Out of these 24 attributes "to make sure that my dairy cows are kept in such a way that I can earn my living from my business" was ranked highest (RBQ: 55.000) and the attribute "to make sure that my dairy production is ethical" was ranked lowest (RBQ: 1.67). The most important attribute which influence the small holders' farmers was found to be "to make sure that my dairy cows are kept in such a way that I can earn my living from my business" which very significant in terms of small holders' dairy. This study indicates that the commercial small holders' dairy farmers are influenced by the use and non-use values in relation to the farm animal welfare. They are specially influenced and motivated by the use values related to production and business development.
\end{abstract}

\section{Introduction}

The total livestock population of Assam is 19.08 million ( $19^{\text {th }}$ Census) out which 10.30 million is cattle population. As per the $19^{\text {th }}$ Livestock Census, Assam houses 9.91 million local/ non descript cattle and 0.34 million (3.8 $\%$ of total cattle population of Assam) Exotic /Cross bred Cattle. The local/ non descript Cattle of Assam is predominantly contributing $57.51 \%$ of total milk production of 799.67 (thousand tones) of Assam where exotic/ 
cross bred cattle contributing $3.58 \%$ and Buffalo contributing only $2.66 \%$ (against National share of $51 \%$ ). As reported in the $19^{\text {th }}$ Livestock Census, the population of the Exotic/ Cross bred in Assam is decreased by $3.55 \%$ in compared to the $18^{\text {th }}$ Livestock Census, whereas, there is an increasing trend in case of local/ non descript cattle by $2.65 \%$ (DAHD, 2012). The state of Assam is lagging behind the commercialization of the dairy farming. Only few pockets are exists in the State where selected people are engaged in dairy farming as a source of livelihood compromising welfare need of the dairy animals in terms of five freedoms as described by Farm Animal Welfare Council.

Farm animal welfare (FAW) is defined in the literature as a human construct that is integrated into the values of humans (Fraser, 1995; Rushen, 2003). Indeed, in the study of human decision-making in relation to FAW, the standard economic welfare assumption is one of anthropocentric welfarism (McInerney, 2004), whereby FAW is a subset of human welfare and the well-being of animals matters only as long as it affects the well-being of humans. This implies that improvements in FAW can be expected only when they affect the well-being of humans. In this context, it is particularly important to understand farmers and their decision-making related to FAW, since farmers make the actual decisions about what FAW-related efforts to provide and hence ultimately determine the living conditions of farm animals.

Human- animal relationships are subjected to two primary dimensions: those of affection and utility, which combine together to give a proper shape in animal welfare often expressed in commercial terms when farmers are involved in running a business on livestock. Although, the farmers may not have a proper technical knowledge of animal welfare, still they want to see their animal happy and try to flourish in the business based on the livestock. Timely and good decision making on the livestock sometimes give animal welfare.

Previous research into the relationship between farmers and their livestock revealed how human-animal interaction affects the welfare and productivity of animals (Hemsworth and Coleman, 1998; Hemsworth et al., 2000; Lensink et al., 2001, Hemsworth, 2003). These studies demonstrated how good care improved the wellbeing of the animals in terms of health and productivity. Identifying farmers' attitudes to farm animal welfare (FAW) is an important step in determining farmers' efforts to improve FAW, knowledge of which is of particular importance for understanding how the living conditions of production animals are determined.

\section{Materials and Methods}

The study was carried out in purposively selected commercial small holders' dairy farms in and around Guwahati under Kamrup (Metro) District of Assam, India as it is the largest dairy pocket in and around the Guwahati city. A total of 60 dairy farmers were selected based on apparently similar shed and animals following minimum scientific management of dairy cattle. A pre tested questionnaire was used for the purpose for preferential ranking of some of the related attributes as proposed by Hansson and Lagerkvist (2016). The primary data were collected by directed interaction with the farmers based on the attributed. All the respondents were asked to rank the attributes in terms of their present dairy farming business individually. These were compiled and the Rank Based Quotient (RBQ) was used to quantify the data collected by preferential ranking technique by first ranking of the attributes then calculating the RBQ given by Sabarathnam (1988) which is as follows: 


$$
\mathrm{RBQ}=\frac{\sum \mathrm{f}_{\mathrm{i}}(\mathrm{n}+1-1) \times 100}{\mathrm{~N} \mathrm{n}}
$$

Wherein,

$\mathrm{f}_{\mathrm{i}}=$ No. of farmers reporting to a particular attribute under $\mathrm{i}^{\text {th }}$ rank

$\mathrm{N}=$ Total number of farmers

$\mathrm{n}=$ No. of attributes identified

$\mathrm{i}=$ Rank of the attribute

\section{Results and Discussion}

During the experiment 24 different attributes were identified for determining the farmers use and non-use value in regards to dairy cow welfare (Table: 1). Out of these 24 attributes "to make sure that my dairy cows are kept in such a way that I can earn my living from my business" was ranked highest (RBQ: 55.000 and the attribute "to make sure that my dairy production is ethical" was ranked lowest (RBQ: 1.67). As par the notation of Hansson and Lagerkvist (2016), the use values represents the reasons concerning (1) maximal production (2) maximal profitability (3) the possibility to continue the business (4) having time available for other things (5) own work environment (6) adjustments of production to current producer prices and (7) making a living from the business. The motivational attributes covering use values included motivating aspects related to maintain productivity and profitability and to achieve business goals may or may not considering the animal welfare aspect. The non-use values were categorized based on the handling of the animals, further scope for improvement of the dairy, ethical production and most importantly the animal welfare criteria indirectly influencing the production and productivity of the animal. Most of the use values were preferentially given higher ranking in comparison to the non use value. However, the non-use value "to feel happy knowing that my dairy cows are well-kept" was given second preferential ranking indicating the motivational aspect of the farmers to keep their animals in good condition significantly influence the animal welfare.

Table.1 Preferential ranking of farmers' use and non-use values in dairy animal welfare on the empirical content based on the RBQ values

\begin{tabular}{|c|l|c|c|c|}
\hline $\begin{array}{l}\text { SI } \\
\text { No. }\end{array}$ & \multicolumn{1}{|c|}{ Attribute } & Categorization & RBQ & Rank \\
\hline $\mathbf{1 .}$ & $\begin{array}{l}\text { To make sure that my dairy cows are kept in such } \\
\text { a way that they can produce as much as possible }\end{array}$ & Use value & 52.25 & 3 \\
\hline 2. & $\begin{array}{l}\text { To make sure that the production of my dairy cows } \\
\text { is at such a level that my business is as profitable } \\
\text { as possible }\end{array}$ & Use value & 38.25 & 7 \\
\hline 3. & $\begin{array}{l}\text { To make sure that my dairy cows are kept in such } \\
\text { a way that I can continue my business }\end{array}$ & Use value & 44.63 & 5 \\
\hline 4. & $\begin{array}{l}\text { To make sure that my dairy cows are healthy, so } \\
\text { that I have time available to do other things }\end{array}$ & Use value & 45.92 & 4 \\
\hline 5. & $\begin{array}{l}\text { To make sure that my dairy cows are kept in such } \\
\text { a way that my work environment is good }\end{array}$ & Use value & 20.00 & 15 \\
\hline 6. & $\begin{array}{l}\text { To make sure that my dairy cows are kept in such } \\
\text { a way that my milk production is adjusted to }\end{array}$ & Use value & 22.92 & 14 \\
\hline
\end{tabular}




\begin{tabular}{|c|c|c|c|c|}
\hline & current producer prices of milk & & & \\
\hline 7. & $\begin{array}{l}\text { To make sure that my dairy cows are kept in such } \\
\text { a way that I can earn my living from my business }\end{array}$ & Use value & 55.00 & 1 \\
\hline 8. & $\begin{array}{l}\text { My interest in good handling of animals, even } \\
\text { though it is currently too expensive to keep the } \\
\text { animals in as good a way as I would like }\end{array}$ & Non-use value & 17.67 & 17 \\
\hline 9. & $\begin{array}{l}\text { For the business to make enough profit for me to } \\
\text { further improve the way my dairy cows are kept }\end{array}$ & Non-use value & 34.67 & 9 \\
\hline 10. & $\begin{array}{l}\text { To feel happy knowing that my dairy cows are } \\
\text { well-kept }\end{array}$ & Non-use value & 53.67 & 2 \\
\hline 11. & $\begin{array}{l}\text { To avoid feeling uncomfortable knowing that my } \\
\text { dairy cows are not well-kept }\end{array}$ & Non-use value & 11.75 & 19 \\
\hline 12. & Dairy cows have a right to be treated well & Non-use value & 42.50 & 6 \\
\hline 13. & To make sure that my dairy production is ethical & Non-use value & 1.67 & 24 \\
\hline 14. & $\begin{array}{l}\text { To feel that I keep my dairy production in the right } \\
\text { way }\end{array}$ & Non-use value & 37.50 & 8 \\
\hline 15. & $\begin{array}{l}\text { To make sure that my dairy cows have free access } \\
\text { to water and that they have a balanced fodder } \\
\text { regimen }\end{array}$ & Non-use value & 33.13 & 10 \\
\hline 16. & $\begin{array}{l}\text { To make sure that my dairy cows have good } \\
\text { housing that offers shelter and comfortable places } \\
\text { for resting }\end{array}$ & Non-use value & 3.50 & 23 \\
\hline 17. & $\begin{array}{l}\text { To make sure that disease, pain, and injury among } \\
\text { my dairy cows are prevented and that diagnosis } \\
\text { and treatment are quickly established if needed }\end{array}$ & Non-use value & 30.33 & 11 \\
\hline 18. & $\begin{array}{l}\text { To make sure that my dairy cows are able to } \\
\text { practice their natural behaviors, for instance by } \\
\text { offering enough space and the company of other } \\
\text { dairy cows }\end{array}$ & Non-use value & 5.75 & 22 \\
\hline 19. & $\begin{array}{l}\text { To prevent my dairy cows feeling fear or in other } \\
\text { ways suffering mentally }\end{array}$ & Non-use value & 28.71 & 12 \\
\hline 20. & $\begin{array}{l}\text { To make sure my dairy cows feel well even when } \\
\text { this requires unprofitable actions }\end{array}$ & Non-use value & 26.00 & 13 \\
\hline 21. & $\begin{array}{l}\text { To contribute to giving consumers the choice to } \\
\text { purchase food products that have been produced } \\
\text { under good animal husbandry, if they would like } \\
\text { to do that }\end{array}$ & Non-use value & 19.13 & 16 \\
\hline 22. & $\begin{array}{l}\text { To make sure that consumers will continue to } \\
\text { demand my production in the long run }\end{array}$ & Non-use value & 15.17 & 18 \\
\hline 23. & $\begin{array}{l}\text { To feel proud that the way I keep my animals is } \\
\text { acknowledged by the industry, market or } \\
\text { consumers }\end{array}$ & Non-use value & 8.17 & 21 \\
\hline 24. & $\begin{array}{l}\text { To contribute to consumers being offered high- } \\
\text { quality food products }\end{array}$ & Non-use value & 9.79 & 20 \\
\hline
\end{tabular}


The most important attribute which influence the small holders' farmers was found to be "to make sure that my dairy cows are kept in such a way that I can earn my living from my business" very significant in terms of small holders' dairy specially in the state of Assam where commercial dairy farming still in primitive stage. However, these commercial small holders' dairy farmers want "to feel happy knowing that their dairy cows are wellkept" indicating the motivation towards the animal welfare.

Hansson and Lagerkvist (2016) in Sweden identified empirically the types of use and non-use values that motivate dairy farmers in their work relating to animal welfare of dairy cows and they prioritize between these use and non-use values. Kielland et al., (2010) also reported that when assessing farmers' attitudes, indicators of negative beliefs, reflected by the disagreement with the statement "animals experience physical pain as humans do", were associated with higher prevalence of skin lesions over the carpus, possibly supporting the relationship between farmers' attitudes, management and care of their animals. Kauppinen et al., (2010) stated thatthe perceived conflict between the farmers' views on the importance of improving animal welfare and the difficulty of putting it into practice indicates that the improvement of animal welfare requires society to take more responsibility.

In conclusion the present study indicates that the commercial small holders' dairy farmers are influenced by the use and non-use values in relation to the farm animal welfare. They are specially influenced and motivated by the use values related to production and business development. They are also interested to be influenced by the non-use values in relation to enhance the welfare of their animals directly or indirectly based on their economic condition to invest on the dairy.

\section{Acknowledgement}

The authors are thankful to Department of Livestock Production and Management, Assam Agricultural University, Khanapara781022 to carry out the research work.

\section{Conflict of Interest Statement}

Authors declare no conflict of interest.

\section{References}

DAHD, (2012). 19 ${ }^{\text {th }}$ Livestock Census-2012, All India Report. Retrieved from http://dahd.nic.in/sites/default/filess/Liv estock\%20\%205_0.pdf.

Fraser, D. (1995). Science, values and animal welfare: exploring the 'inextricable connection'. Animal Welfare. 4(2): 103-117.

Rushen, J. (2003). Changing concepts of animal welfare: bridging the gap between applied and basic research. Applied Animal Behaviour Science. 81(3):199-214.

McInerney, J. (2004). Animal welfare, economics and policy. Report on a Study Undertaken for the Farm \& Animal Health Economics Division of Defra, Exeter, UK. Retrieved from https://www.semanticscholar.org/paper/ Animal-Welfare\%2C-Economics-andPolicy-Report-on-a-\%26-McInerney /3ee106ec1b5c7e58e0ff2144a 11057ab23347486

Hemsworth, P.H. and Coleman, G. J. (1998). Human-Livestock interactions: the stockperson and the productivity and welfare of intensely farmed animals. CAB International, New York.

Hemsworth, P.H., Coleman, G. J., Barnett, J. L. and Borg, S. (2000). "Relationships between human-animal interactions and productivity of commercial dairy cows". Journal of Animal Science. 78 
(11): 2821-2831.

Lensink, B. J., Veissier, I. and Florand, L. (2001). "The farmers' influence on calves' behaviour, health and production of a veal unit". Animal Science. 72(1): 105-116.

Hemsworth, P. H. (2003). Human-animal interactions in livestock production. Applied Animal Behaviour Science. 81(3): 185-198.

Hansson, H. and Lagerkvist, C. J. (2016). Dairy farmers' use and non-use values in animal welfare: Determining the empirical content and structure with anchored best-worst scaling. Journal of Dairy Science. 99(1): 579-592.
Sabarathanam, V. E. (1988). Manuals of Field Experience Training for ARS Scientists. NAARM, Hyderabad.

Kielland. C., Skjerve, E., Osteras, O., Zanella, A. (2010). Dairy farmer attitudes and empathy toward animals are associated with animal welfare indicators. Journal of Dairy Science. 93(7): 2998-3006.

Kauppinen, T., Vainio, A., Valros, A., Rita, H. and Vesala, K. M. (2010). Improving animal welfare: qualitative and quantitative methodology in the study of farmers' attitudes. Animal Welfare. 19(4): 523-536.

\section{How to cite this article:}

Chinmoy Dutta, Raj Jyoti Deka, Jyoti Pawan Chutia and Aditya Boruah. 2020. Preferential Ranking of Farmers' Attributes Associated with Welfare of Cross Bred Dairy Cattle in Small Holders' Production System in Assam. Int.J.Curr.Microbiol.App.Sci. 9(07): 3932-3937. doi: https://doi.org/10.20546/ijcmas.2020.907.461 